\title{
Comprehensive Evaluation of Quality Soda
}

\author{
Lutfu S Sua ${ }^{1}$ and Figen Balo ${ }^{2 *}$ \\ ${ }^{1}$ Industrial engineering, Turkey \\ ${ }^{2}$ Firat university, Turkey
}

Submission: August 11, 2017; Published: August 23, 2017

*Corresponding author: Figen Balo, Frrat University Industrial Engineering Department, Turkey, Tel: +90-0424-2370000;

Email: figenbalo@gmail.com

\begin{abstract}
The mineral waters (soda) are found in great amount of abundance with diverse chemical characteristics in the World. The mineral waters' chemical contents are primarily based on the geological background, in relation tolithology and structure. The water's chemical composition supplies significant information on the operation of the mineral-hydro system. With the important rise in bottled soda consumption in recent years, there has been a growing interest on the ingredients' quality of mineral water brands. The numerous bottled soda brands have diverse chemical contents and properties such as good taste, convenience, and quality. The aim of this paper is to determine of the most proper bottled soda type for consumers. For this purpose, ten bottled soda brand alternatives are compared.
\end{abstract}

These soda brands' primary characteristics and their attributes were obtained. The AHP (analytical hierarchy process) methodology performed for comparative analysis is an approach for multi-criteria decision making with complex problems that can be assessed considering the eight parameters in mineral water. With the help of questionnaires, required data were compiled, which made the evaluation possible.

Keywords: Quality; AHP; Mineral water; Soda; Multi-criteria

\section{Introduction}

There has been a huge rise in consumer demand for mineral waters worldwide over the last decade. Figure 1 shows soft drink terms in the world [1]. The carbonated soft drink top consumers and annual global soda consumption versus GDP

per capita is displayed in Figure 2 [2]. Global soda consumption is increasing at about the same proportion as population. The soda consumption per person and global soda consumption as population is shown in Figure 3 [1,2].

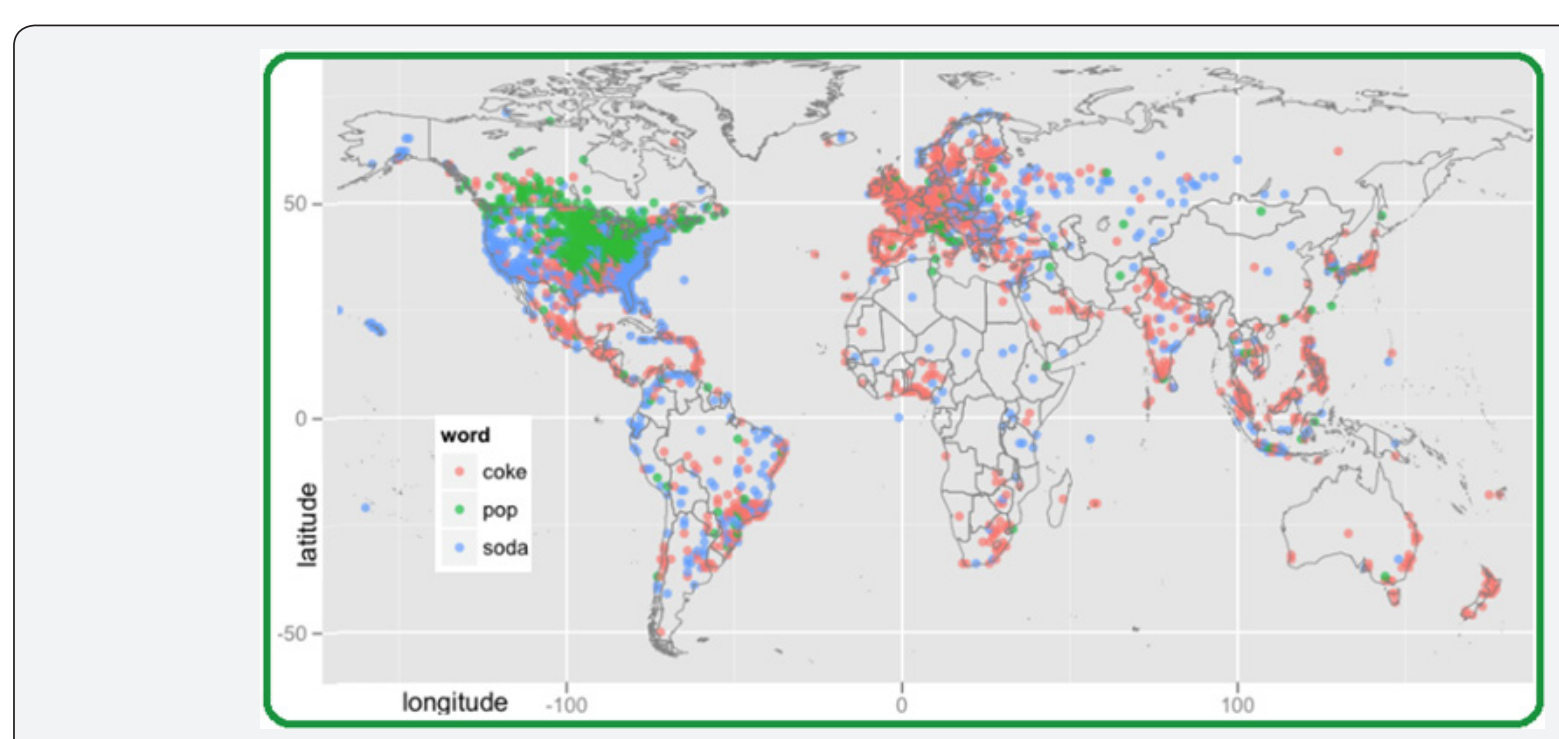

Figure 1: Soft drink terms in the world. 


\section{Civil Engineering Research Journal}

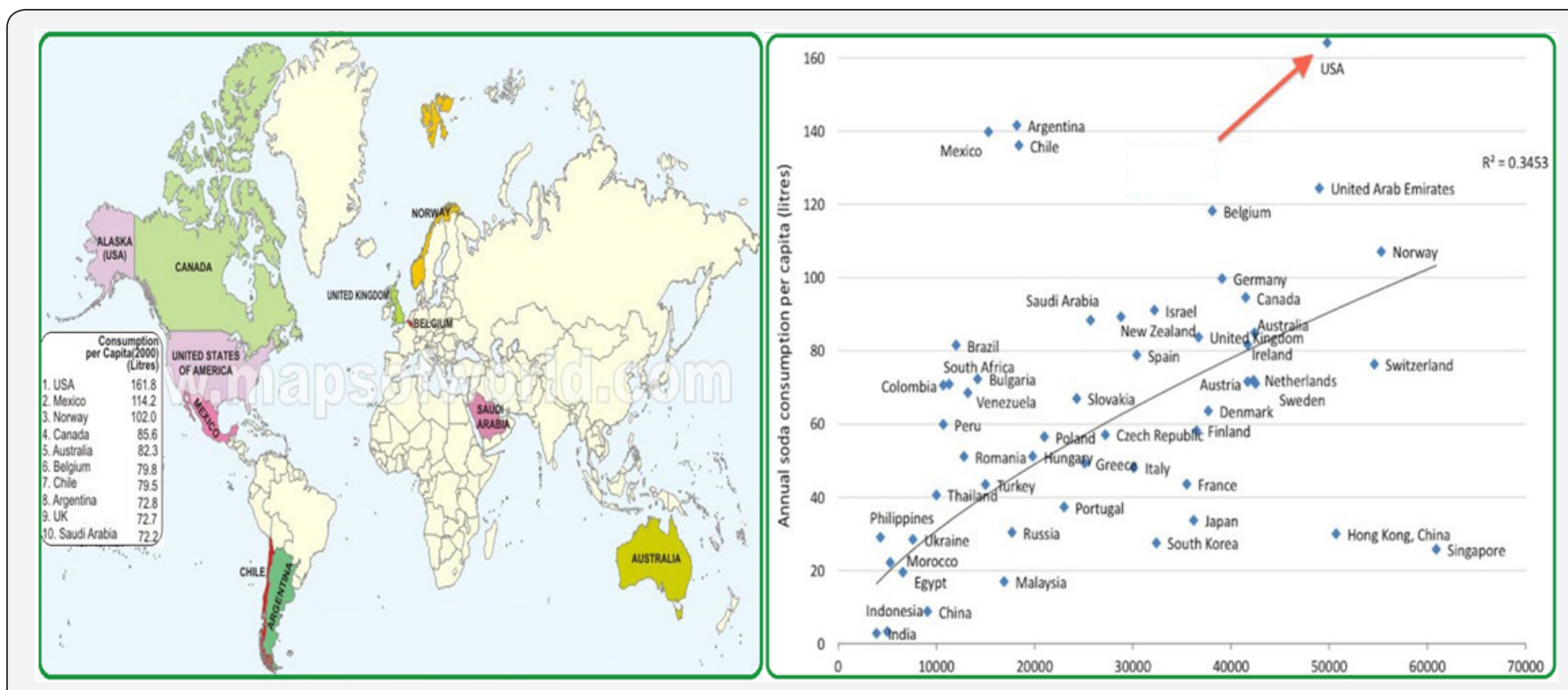

Figure 2: A-Carbonated soft drink top consumers b-Annual global soda consumption vesus GDP per capita.

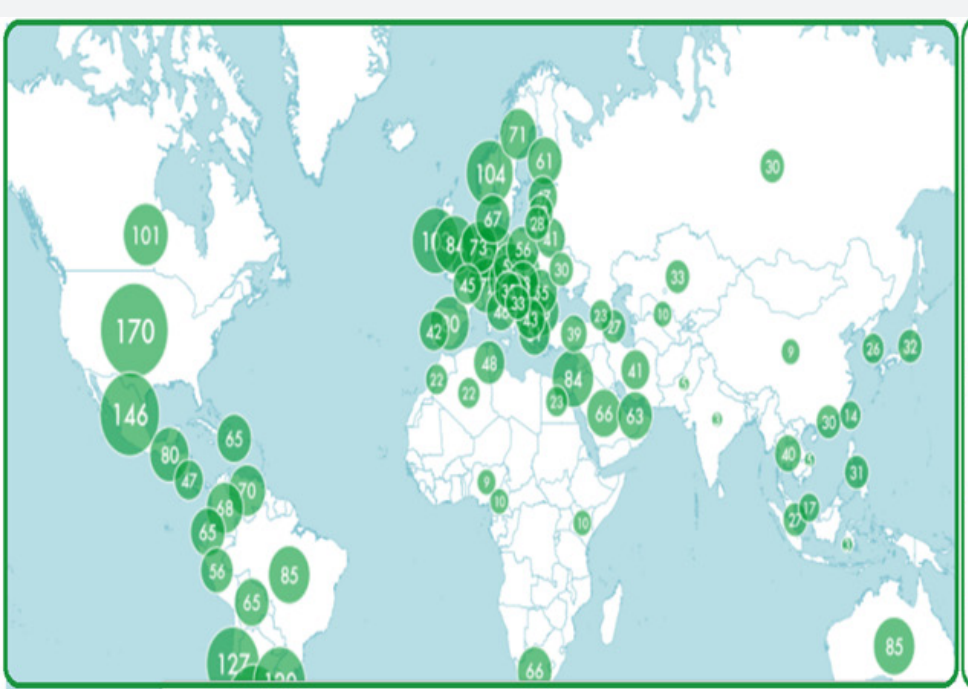

(a)

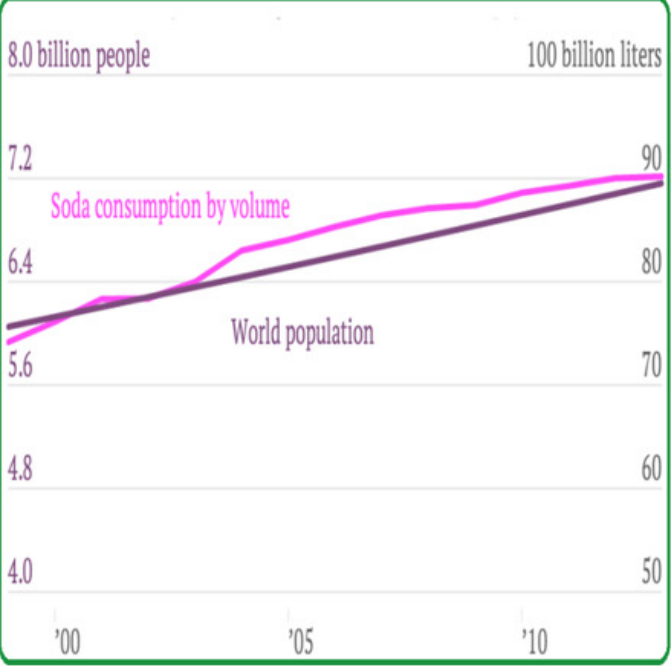

(b)

Figure 3: a-Soda consumption per person [3] b-Global soda consumption as population [4].

The advantageous impact of fixed kinds of soda on human organism depends on their particular chemical-physical properties. Soda has outstanding taste values. Fixed categories of mineral, according to proper chemical-physical properties display medical impact on human health in bigger amount than normal. Furthermore, it supplies fundamental elements such as calcium, iron, magnesium, etc. [3-5].

Nevertheless, when contaminated it may become the resource of unwanted items as bacteria in addition to inorganic and organic chemicals hazardous to human health. For example; $\mathrm{NO}_{3}$ in chemicalreaction with amines creates nitrosamines, which are potency mutagens, teratogens, and/or carcinogens [6].
$\mathrm{NO}_{2}$ can be related to hemoglobin shaping meta-hemoglobin by oxidation of $\mathrm{Fe}^{+3}$ to $\mathrm{Fe}^{+2}$ troublesome for the capability of blood to move oxygen [7]. Some of the metals available in soda, such as molybdenum and chromium are fundamental foods which, in excess, can induce metabolical disturbances [8]. Because of general numerous minerals, they also include radioactive materials such as potassium, lead, polonium, uranium and radium $[9,10]$.

Mineral waters have ever attracted attention of users and researchers worldwide. A comparison of the soda quality proves that the bottled mineral waters possess much better quality concerning $\mathrm{pH}$ contaminations, aesthetic considerations, and 


\section{Civil Engineering Research Journal}

microbial hazards. To assess the quality of mineral waters according to the important criteria, some methods are used with which the several elements are valued: total mineralization, sulphates, bromine, $\mathrm{pH}$ value, water temperature, sodium, magnesium, hydro carbonates, calcium, ions, lithium, strontium, meta boric acid, chlorides, iodine, fluorine, meta silicon, $\mathrm{CO}_{2}$ gas etc. The aim of this paper is to analyze the safety and quality of bottled soda brands sold in Turkey.

Though a few qualitative researches of the microbiology of bottled soda brands have been investigated in various countries [11-14]. The nine different characteristics, which are TDS, magnesium, calcium, $\mathrm{pH}$, nitrate, chlorides, sulphates, total hardness, and fluorides considered by Ambiga et al. [15]. Saidi et al. [16] used five diverse characteristics (nitrate, calcium, electrical conductivity, chlorides, and sulphates) depending on technical documents published in WHO [17], WCCR [18], and Anon [19]. By using the fuzzy analytic hierarchy process, Mokarram and Sathyamoorthy evaluated the connection between water quality index based on landform classes and composition of nonorganic components in Iran [20]. For water quality assessment, the aim weighting methodologies cover the entropy weight methodology implemented by Zou et al. [21]. The entropy weighting methodology is performed to appraisal the groundwater quality with logical results by Amiri et al. [22]. Yan et al. studied the comprehensive evaluation of drinking water quality based on field studies, information technology, GIS, and modeling [23]. Alvarado et al. [24] analyzed the groundwater supply source for public by using Geographic Information System.

The aim of this study is to use AHP methodology to perform the ranking of measuring points based on multi-criteria decision making. The selection of the best bottled soda from ten different alternative brands is a complicated task since eight decision criteria need to be noted simultaneously. Based on the data obtained from General Directorate of State Hydraulic Works, the obtained results by this way are evaluated from various Table 1: Decision Matrix.

\begin{tabular}{|c|c|c|c|c|c|c|c|c|}
\hline & Fluoride & Bicarb & Chloride & Sulfates & Calcium & Magnesium & Potassium & Sodium \\
\hline fluoride & 1,00 & 1,00 & 1,00 & 4,00 & 1,00 & 8,00 & 4,00 & 4,00 \\
\hline bicarb & 1,00 & 1,00 & 1,00 & 4,00 & 1,00 & 8,00 & 4,00 & 4,00 \\
\hline chloride & 1,00 & 1,00 & 1,00 & 4,00 & 1,00 & 8,00 & 4,00 & 4,00 \\
\hline sulfates & 0,25 & 0,25 & 0,25 & 1,00 & 0,25 & 4,00 & 1,00 & 1,00 \\
\hline calcium & 1,00 & 1,00 & 1,00 & 4,00 & 1,00 & 8,00 & 4,00 & 4,00 \\
\hline magnesium & 0,13 & 0,13 & 0,13 & 0,25 & 0,13 & 1,00 & 0,25 & 0,25 \\
\hline potassium & 0,25 & 0,25 & 0,25 & 1,00 & 0,25 & 4,00 & 1,00 & 1,00 \\
\hline sodium & 0,25 & 0,25 & 0,25 & 1,00 & 0,25 & 4,00 & 1,00 & 1,00 \\
\hline
\end{tabular}

Table 2: Factor Priorities.

\begin{tabular}{|c|c|c|c|c|c|c|c|}
\hline Fluoride & Bicarbonate & Magnesium & Chloride & Potassium & Sulfate & Calcium & Sodium \\
\hline 0,2027 & 0,2027 & 0,2027 & 0,0562 & 0,2027 & 0,0205 & 0,0562 \\
\hline
\end{tabular}
water brand choice is obtained.

\section{AHP Methodology}

In an AHP hierarchy for choosing an alternative over the others, the goal would be to make a decision based on various criteria. For the purpose of this study, a set of criteria in a soda water are included. Five alternative soda water brands are compared using AHP technique. The hierarchy composed of these criteria is constructed as shown in the Figure 4.

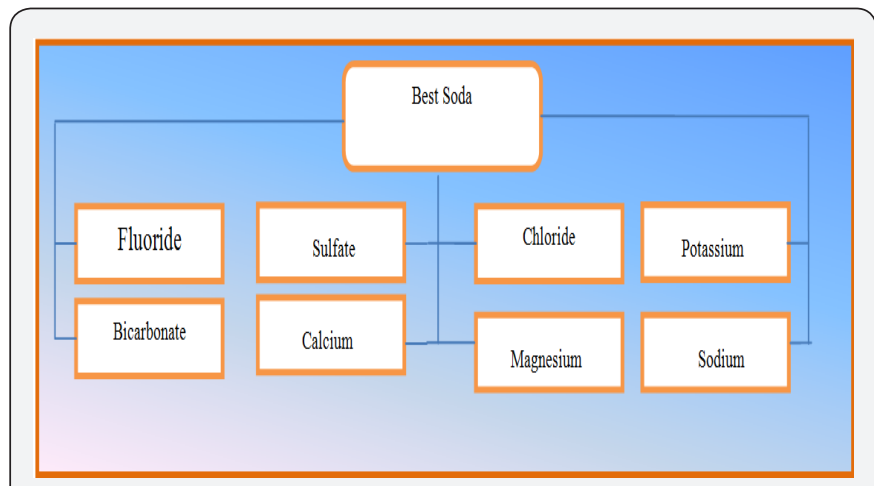

Figure 4: Hierarchy of Factors.

Each of the ingredients mentioned in the figure above plays vital roles in human life. For instance, the more magnesium and calcium exist, the harder the water is. People who drink soft water have an increased risk of heart disease compared to people who drink hard water. However, the real reason may simply be that hard water is more likely to contain sulfur. Even the smaller amounts of minerals found in regular drinking water play a beneficial role in human organism. Calcium and magnesium are important for strong bones as well. Magnesium also helps to regulate the blood pressure. Our bodies need the right amounts of minerals, and sulfates are harder to get and unappreciated. The benefits of getting more sulfates are diverse, supporting joint, muscle, and nervous system health and detox [25]. attributes by AHP. Among chosen soda brands, the best mineral 


\section{Civil Engineering Research Journal}

While measurements for some criteria are readily available, some others can only be estimated with respect to other variables. As it is the case in all multi-criteria decision making methods, the relative weights of such criteria need to be determined. In AHP, this is accomplished by pairwise comparison of the elements.
Below are the resulting priorities of factors involved in this research (Table 1). Based on the decision matrix provided above, the relative weights of the factors defined are provided in the Table 2 below.

\section{Pairwise comparison of the soda waters}

Table 3: Soda Water Characteristics.

\begin{tabular}{|c|c|c|c|c|c|c|c|c|c|c|}
\hline & Uludă & Kızılay & Akmina & Kınık & Ozkaynak & Perrier & Sarıkız & Beypazarı & $\begin{array}{c}\text { Sen- } \\
\text { Pelegrino }\end{array}$ & Sırma \\
\hline Bicarb & 1493 & 2123 & 1383 & 3050 & 1037 & 445 & 598 & 1865 & 239 & 1634 \\
\hline Calcium & 223,6 & 40,8 & 393,2 & 227,6 & 116,8 & 155 & 83,7 & 225,5 & 179 & 326 \\
\hline Magn & 81,4 & 13,3 & 28,8 & 126,2 & 102,2 & 6,8 & 62,12 & 108,4 & 52 & 111,4 \\
\hline Sodium & 189,8 & 770,4 & 22,2 & 684,5 & 72,59 & 11,8 & 58,23 & 265,2 & 34 & 425 \\
\hline Potassium & 28,9 & 5,4 & 5,36 & 44,39 & 10,68 & 0 & 5,75 & 63,01 & 2 & 53,6 \\
\hline Fluoride & 1,3 & 0,81 & 0,54 & 1,37 & 0,74 & 0 & 0,23 & 0,46 & 0 & 1,4 \\
\hline Chloride & 95,1 & 97,4 & 5,05 & 37,53 & 32,4 & 25 & 14,53 & 25,77 & 55 & 166 \\
\hline Sulfate & 26,9 & 5,35 & 9,52 & 83,54 & 15,7 & 46,1 & 87,8 & 138,3 & 445 & 6 \\
\hline
\end{tabular}

After determining the priorities of each criterion with respect to the overall goal of selecting the best soda water, the water alternatives need to be compared two by two with respect to each criterion. The properties of the selected water brands are presented in the table below (Table 3).

The next step in applying the AHP technique is two by two comparisons of the water alternatives with respect to each criterion. In order to design an objective scheme for this purpose, the maximum and minimum values of the alternatives for each criterion is determined. This range is divided into nine even ranges since AHP requires pairwise comparisons on a scale from 1 to 9. Finally each alternative is placed in one of these classes based on their values to compare them with each other. Remainder of this research presents the priorities obtained under each category using this scheme.

\section{Conclusion}

Table 4: Weights of Alternatives.

\begin{tabular}{|c|c|c|c|c|c|c|c|c|c|}
\hline & Bicarb & Calcium & Magn & Sodium & Potass & Fluoride & Chloride & Sulfate & Total \\
\hline SW1 & 0,0181 & 0,0169 & 0,0172 & 0,0034 & 0,0208 & 0,0045 & 0,0089 & 0,0030 & 0,0926 \\
\hline SW2 & 0,0318 & 0,0054 & 0,0043 & 0,0199 & 0,0062 & 0,0018 & 0,0089 & 0,0030 & 0,0813 \\
\hline SW3 & 0,0135 & 0,0682 & 0,0049 & 0,0018 & 0,0062 & 0,0010 & 0,0021 & 0,0030 & 0,1007 \\
\hline SW4 & 0,0709 & 0,0169 & 0,0539 & 0,0134 & 0,0353 & 0,0045 & 0,0024 & 0,0032 & 0,2004 \\
\hline SW5 & 0,0093 & 0,0066 & 0,0317 & 0,0018 & 0,0066 & 0,0014 & 0,0024 & 0,0030 & 0,0627 \\
\hline SW6 & 0,0053 & 0,0088 & 0,0043 & 0,0018 & 0,0062 & 0,0005 & 0,0024 & 0,0030 & 0,0321 \\
\hline SW7 & 0,0065 & 0,0066 & 0,0130 & 0,0018 & 0,0062 & 0,0005 & 0,0021 & 0,0032 & 0,0400 \\
\hline SW8 & 0,0239 & 0,0169 & 0,0317 & 0,0047 & 0,0669 & 0,0008 & 0,0024 & 0,0050 & 0,1522 \\
\hline SW9 & 0,0053 & 0,0134 & 0,0099 & 0,0018 & 0,0062 & 0,0005 & 0,0029 & 0,0270 & 0,0669 \\
\hline SW10 & 0,0181 & 0,0432 & 0,0317 & 0,0061 & 0,0421 & 0,0050 & 0,0218 & 0,0030 & 0,1710 \\
\hline
\end{tabular}

This study aims to find the best soda water brand based on various minerals and elements exist in soda waters. A list of criteria is evaluated to be able to make a comparison among the selected brands. Each criterion is appointed a relative weight as a result of expert evaluations obtained from Ministry of Health Reports available. Finally, AHP method is applied to the resulting scheme. Based on the calculations above, the relative priorities corresponding to the attractiveness of soda water brand about all factors considered are presented below (Table 4). The table above indicates that the $4^{\text {th }}$ Soda Water (SW4) is ranked first with a weight of 0,2004 among others, indicating that it is the best soda water in terms of selected factors used for the purpose of this study.

\section{References}

1. (2011) Euromonitor International

2. (1902) Euromonitor, US Cesus Burau, Suitland, Maryland, USA.

3. Constans T, Deschasse G, Chavanne D (2009) Indications and therapeutic use of vitamin D and calcium. Les cahiers de l'année gérontologique 1 (3): 196-200. 


\section{Civil Engineering Research Journal}

4. Suheyl A, Can B, Hakan O (2009) Safety, therapeutic effectiveness, and cost of parenteral iron therapy. Int J Hematol 90(1): 24-27.

5. Zehender M, Meinertz T, Just H (1997) Magnesiummangel and magnesiumsubstitution. Herx 22: 56-62.

6. Connolly D, Paul B (2001) Rapid determination of nitrate and nitrite in drinking watersamples using ion-interaction liquid chromatography. Anal Chim Acta 441: 53-62

7. Bruning-FCS, Kaneene JB (1993) The effects of nitrate nitrite and N-nitroso compounds on human health: a review. Vet Hum Toxicol 35(6): 521-538.

8. Yao W, Byrne RP (1999) Determination of trace chromium (VI) and molybdenum (VI) in natural and bottled mineral waters using long pathlength absorbance spectroscopy (LPAS). Talanta 48: 277-282.

9. Chau ND, Michelec B (2009) Natural radioactivity in bottled natura spring, mineral andtherapeutic waters in Poland. J Radioanal Nucl Chem 279(1): 121-129.

10. De Olivera J, Mazzilli BP, Da Costa P, Tanigava PA (2001) Natural radioactivity in Brazilian bottled mineral waters and consequent doses. J Radioanal Nucl Chem 249(1): 173-176.

11. Da Silva MEZ, Santana RG, Guilhermetti M, Filho IC, Endo EH, UedaNT, et al. (2008) Comparison of the bacteriological quality of tap water and bottled mineral water. International Journal of Hygiene and Environmental Health 211: 504-509.

12. Tsai GJ, Yu SC (1997) Microbiological evaluation of bottled uncarbonated mineral water in Taiwan. Int J Food Microbiol 37(2-3) 137-143.

13. Warburton DW, Bowen B, Konkle A (1992) The survival and recovery of Pseudomonas aeruginosa and its effect upon salmonellae in water: methodology to test bottled water in Canada. Can J Microbio 40(12) 987-992.

14. Zeenat A, Hatha AAM, Viola L, Vipra K (2009) Bacteriological quality and risk assessment of the imported and domestic bottled minera water sold in Fiji. Journal of Water and Health 7(4): 642-649.

15. Ambiga K, Anna DR (2013) Use of geographical information system and water quality index to assess groundwater quality in and around
Ranipet area, Vellore district, Tamil Nadu. Int J Adv Eng Res Stud 2(4): $73-80$

16. Stigter TY, Ribeiro AMM, Carvalho DL (2006) Application of a ground water quality index as an assessment and communication tool inagroenvironmental policies-two Portuguese case studies. J Hydrol 327: 578-591.

17. WHO (2006) Guidelines for Drinking-water Quality. ( $3^{\text {rd }}$ edn), WHO press, Cambridge, England, pp. 595.

18. WCCR (1991) Water Contamination control regulations, Resmi Gazete No. 19919, State printing offic , Ankara, Turkey.

19. Anon (2003) Système d'évaluation de la qualité des eaux souterraines SEQ-Eaux Souterraines. Rapport de présentation, version 0.1 Août 2003, SIGES, Bretagne, France, pp. 75.

20. Marzieh M, Dinesh S (2016) Investigation of the relationship between drinking water quality based on content of inorganic components and landform classes using fuzzy AHP (case study: south of Firozabad, west of Fars province, Iran), Drink. Water Eng Sci 9: 57-67.

21.Zou ZH, Yi Y, Sun JN (2006) Entropy method for determination of weight of evaluating indicators in fuzzy synthetic evaluation for water quality assessment. J Environ Sci 18 (5): 1020-1023.

22. Amiri V, Rezaei M, Sohrabi N (2004) Groundwater quality assessment using entropy weighted water quality index (EWQI) in Lenjanat, Iran. Environ Earth Sci 72 (9): 3479-3490.

23. Weiwu Y, Jialong Li, Xiaohui B (2016) Comprehensive assessment and visualized monitoring of urban drinking water quality, Chemometrics and Intelligent Laboratory Systems 155 (2016): 26-35.

24. Alvarado A, Esteller MV, Quentin E, Expósito JL (2016) Multi-Criteria Decision Analysis and GIS Approach for Prioritization of Drinking Water Utilities Protection Based on their Vulnerability to Contamination. Water Resour Manage 30(4): 1549-1566.

25. Stephanie S, Lauritzen A, Robert D, Laurie LM (2012) Is Endothelial Nitric Oxide Synthase a Moonlighting Protein Whose Day Job is Cholesterol Sulfate Synthesis? Implications for Cholesterol Transport, Diabetes and Cardiovascular Disease. Entropy 14(12): 2492-2530.

\section{Your next submission with Juniper Publishers will reach you the below assets}

- Quality Editorial service

- Swift Peer Review

- Reprints availability

- E-prints Service

- Manuscript Podcast for convenient understanding

- Global attainment for your research

- Manuscript accessibility in different formats

( Pdf, E-pub, Full Text, Audio)

- Unceasing customer service

Track the below URL for one-step submission https://juniperpublishers.com/online-submission.php 